\title{
Article \\ Time-Dependent Changes in Protein Composition of Medial Prefrontal Cortex in Rats with Neuropathic Pain
}

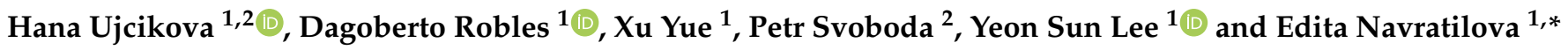 \\ 1 Department of Pharmacology, University of Arizona, Tucson, AZ 85724, USA; \\ hana.ujcikova@fgu.cas.cz (H.U.); roblesdagoberto@email.arizona.edu (D.R.); xyue@email.arizona.edu (X.Y.); \\ yeon@email.arizona.edu (Y.S.L.) \\ 2 Department of Neurochemistry, Institute of Physiology of the Czech Academy of Sciences, \\ 14220 Prague, Czech Republic; svobodap@fgu.cas.cz \\ * Correspondence: edita@email.arizona.edu
}

check for updates

Citation: Ujcikova, H.; Robles, D.; Yue, X.; Svoboda, P.; Lee, Y.S.; Navratilova, E. Time-Dependent Changes in Protein Composition of Medial Prefrontal Cortex in Rats with Neuropathic Pain. Int. J. Mol. Sci. 2022, 23, 955. https://doi.org/ 10.3390/ijms23020955

Academic Editors: Joong Woo Leem and Young-seob Gwak

Received: 21 December 2021

Accepted: 14 January 2022

Published: 16 January 2022

Publisher's Note: MDPI stays neutral with regard to jurisdictional claims in published maps and institutional affiliations.

Copyright: (C) 2022 by the authors. Licensee MDPI, Basel, Switzerland. This article is an open access article distributed under the terms and conditions of the Creative Commons Attribution (CC BY) license (https:// creativecommons.org/licenses/by/ $4.0 /)$.

\begin{abstract}
Chronic pain is associated with time-dependent structural and functional reorganization of the prefrontal cortex that may reflect adaptive pain compensatory and/or maladaptive painpromoting mechanisms. However, the molecular underpinnings of these changes and whether there are time-dependent relationships to pain progression are not well characterized. In this study, we analyzed protein composition in the medial prefrontal cortex ( $\mathrm{mPFC}$ ) of rats at two timepoints after spinal nerve ligation (SNL) using two-dimensional gel electrophoresis (2D-ELFO) and liquid chromatography with tandem mass spectrometry (LC-MS/MS). SNL, but not sham-operated, rats developed persistent tactile allodynia and thermal hyperalgesia, confirming the presence of experimental neuropathic pain. Two weeks after SNL (early timepoint), we identified 11 proteins involved in signal transduction, protein transport, cell homeostasis, metabolism, and apoptosis, as well as heat-shock proteins and chaperones that were upregulated by more than 1.5-fold compared to the sham-operated rats. Interestingly, there were only four significantly altered proteins identified at 8 weeks after SNL (late timepoint). These findings demonstrate extensive time-dependent modifications of protein expression in the rat $\mathrm{mPFC}$ under a chronic neuropathic pain state that might underlie the evolution of chronic pain characterized by early pain-compensatory and later aberrant mechanisms.
\end{abstract}

Keywords: neuropathic pain; affective dimension of pain; pain chronification; prefrontal cortex; proteomics

\section{Introduction}

Chronic pain patients often suffer from negative emotional, affective, and cognitive consequences that cause a substantial burden on their lives. Chronic pain, therefore, represents a multifaceted disease state that differs from acute somatosensory or transient injury-driven pain conditions. Chronic pain has been suggested to result from changes occurring in multiple parts of the neuraxis, including primary afferent nociceptors [1] and in output cells of the spinal dorsal horn through a net loss of inhibition [2,3] or from morphological and functional changes in the cortex and other brain regions [4-7]. To date, however, the only drugs that have demonstrated clinical efficacy in chronic pain are those with predominant sites of action in the brain, including opioids, reuptake blockers, and gabapentinoids [8-10]. For example, in a study of 170 patients with neuropathic pain, 22 days of intrathecal delivery of gabapentin provided no pain relief [11]. Both human and animal studies have consistently implicated the medial prefrontal cortex (mPFC) in pain processing, especially for the emotional and cognitive aspects of pain [7]. Our previous studies in rodents also suggest that morphine and gabapentin might act primarily in the $\mathrm{mPFC}$ to alleviate aversive aspects of chronic pain [12-14].

The human $\mathrm{mPFC}$ typically refers to the dorsolateral prefrontal cortex, the anterior cingulate cortex (ACC), and the orbitofrontal, dorsomedial, and ventromedial cortices, 
while the rodent $\mathrm{mPFC}$ consists of the ACC, and prelimbic and infralimbic cortices. Importantly, the role of MPFC in aversive aspects of pain has been well characterized by both human and rodent studies [9,14-16]. The mPFC is also involved in analgesia and pain modulation $[16,17]$. Activations in this region have been demonstrated in humans during placebo-induced analgesia [18], after relief of neuropathic pain [19,20], and with the termination of a prolonged noxious thermal stimulation [21]. Recent studies in mice with neuropathic pain demonstrated decreased excitability of prelimbic layer $\mathrm{V}$ pyramidal neurons [22]. Accordingly, optogenetic activation of prelimbic mPFC inputs to the periaqueductal gray relieved neuropathic pain [23]. These findings suggest that activation of some mPFC neurons during pain may be linked to the engagement of adaptive, pain compensatory mechanisms, as well as placebo analgesia. It was also suggested that chronic pain might result from a failure to engage pain resolution mechanisms rather than from a transition from acute pain [24]. Altogether, neural changes in the MPFC may initially reflect adaptive changes that engage pain compensatory mechanisms that could be lost after pain chronification. Alternatively, or in addition, changes in the MPFC may reflect maladaptive changes that develop over time and contribute to chronic pain.

The ACC within the MPFC has been demonstrated to encode the aversive components of pain and to modulate pain perception through its connections to descending pain pathways [23,25]. Accordingly, microinjection of excitatory amino acids into the rostral ACC of uninjured rats produced conditioned place aversion reminiscent of an aversive pain state [26]. In contrast, rostral ACC lesion abolished pain-induced aversive behavior $[15,27,28]$. Several ion channels, receptors, kinases, and signal transduction molecules have been found to promote pain-related synaptic plasticity in the MPFC, although a systematic and time-dependent proteomic analysis in the MPFC has not yet been conducted.

Recently, neuroimaging studies of patients with chronic pain have uncovered profound morphological and functional reorganization in these brain regions including changes in the pain-related activity, which could explain the high co-occurrence of emotional and cognitive problems associated with chronic pain [4-7]. For example, a longitudinal study that followed the same back pain patients over 1 year discovered that brain activity in regions associated with acute pain diminished over time, while the activity in emotion-related brain regions increased [29]. Moreover, a neuroimaging study in rats also demonstrated time-dependent alterations in the ACC and $\mathrm{MPFC}$ regions in animals with persistent neuropathic pain [30], confirming that key mechanisms of acute and chronic pain processing in the brain are conserved in rats despite significant cortical differences across species. Collectively, both human and preclinical findings in animals suggest that mPFC brain circuits undergo remodeling that might underlie a hypothesized transition to a chronic maladaptive pain state.

Taken together, we postulated that the transition to a chronic pain state will be reflected by time-dependent changes in protein expression in the $\mathrm{MPFC}$ of rats with chronic neuropathic pain. To investigate this possibility, we collected the mPFC encompassing the anterior cingulate, prelimbic, and infralimbic cortices of rats with spinal nerve ligation (SNL)-induced neuropathic pain or sham-operated controls and analyzed protein composition by two-dimensional gel electrophoresis (2D-ELFO) and liquid chromatography with tandem mass spectrometry (LC-MS/MS) at early (2 weeks) and late (8 weeks) timepoints following the surgery. Neuropathic pain state was confirmed over time by measuring tactile allodynia and thermal hyperalgesia.

\section{Results}

\subsection{Pain Behavior}

At 2 weeks following SNL or sham surgery, SNL rats showed significantly lower paw withdrawal thresholds and latencies compared to the baseline, demonstrating the development of tactile allodynia (Figure 1a) and thermal hyperalgesia (Figure 1b), respectively. In contrast, neither mechanical nor thermal withdrawal responses were significantly altered 
in sham-operated rats at this timepoint. In both tests, two-way RM ANOVA demonstrated a significant effect of time, surgery, and interaction ( $p<0.0001$ for all factors), but not of subject. Post hoc multiple comparisons test showed a significant difference between sham and SNL groups (Figure 1a,b, solid lines; $p<0.0001$ ). Every individual SNL rat showed a lower threshold and latency than every individual sham-operated rat (Figure $1 \mathrm{a}, \mathrm{b}$, dotted lines).

a)

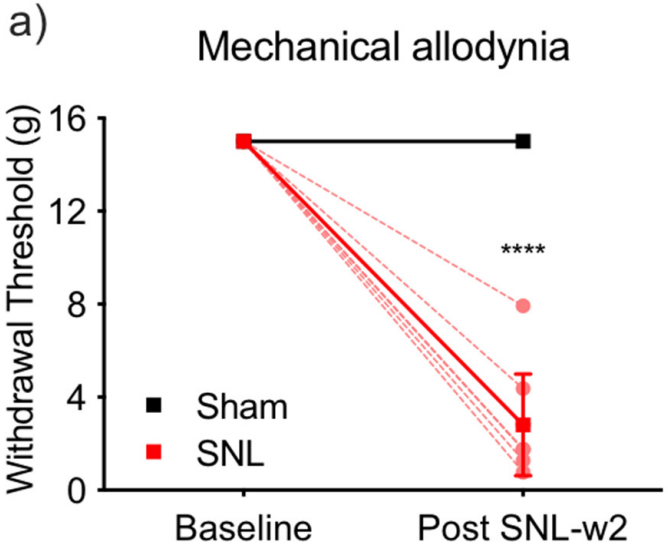

c)

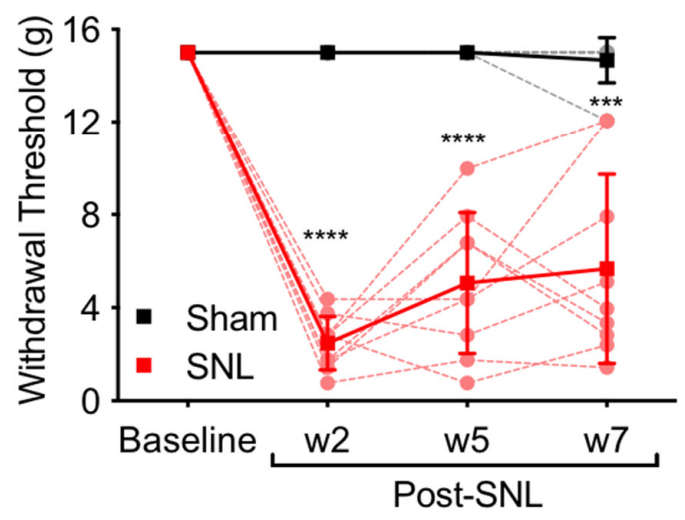

b)

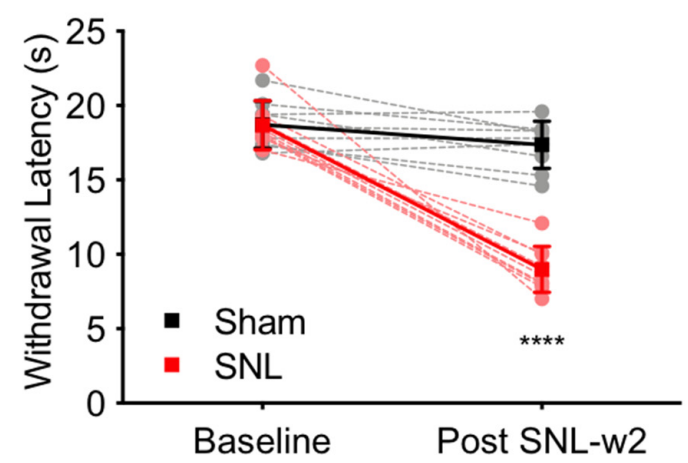

d)

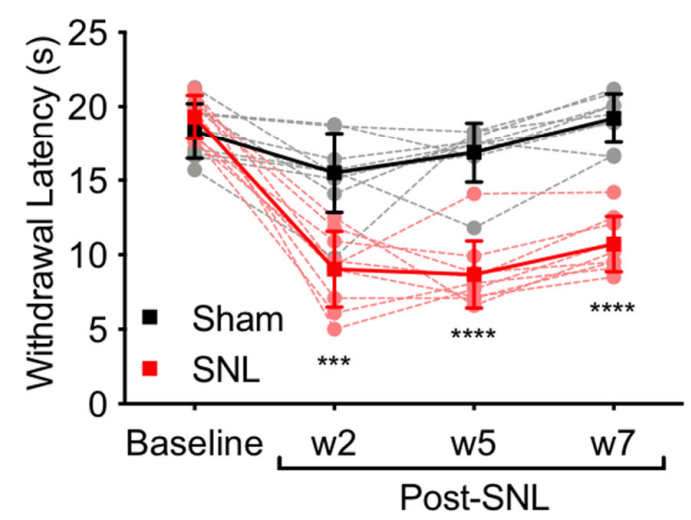

Figure 1. Mechanical and thermal responses for SNL and sham-operated rats: Pain responses of the 2 week groups (nine SNL rats and nine sham rats): (a) mechanical allodynia and (b) thermal hyperalgesia were measured at baseline (before surgery) and at 2 weeks (w2) post SNL surgery. Pain responses of the 8 week groups (nine SNL rats and nine sham rats): (c) mechanical allodynia and (d) thermal hyperalgesia were measured at baseline (before surgery) and at 2, 5, and 7 weeks post SNL surgery. Average group data with SEM and individual data are plotted as solid lines and dotted lines, respectively; ${ }^{* * *} p<0.0005,{ }^{* * * *} p<0.0001$, compared with baseline in the same group.

In another cohort of SNL and sham-operated animals, tactile allodynia and thermal hyperalgesia were evaluated at 2,5, and 7 week timepoints after the surgery (see methods for details). The SNL group developed long-lasting tactile allodynia and thermal hyperalgesia indicated by significant decreases from baseline in paw withdrawal thresholds and latencies at all timepoints (Figure 1c,d), while the sham-operated rats did not show decreased mechanical or thermal withdrawal responses. Two-way RM ANOVA demonstrated a significant effect of time, surgery, and interaction $(p<0.0001$ for all factors) on the thermal and tactile responses; there was a significant $(p=0.024)$ effect of subject for the thermal but not tactile responses. Post hoc test demonstrated a significant difference in tactile allodynia and thermal hyperalgesia between sham and SNL groups at all timepoints (Figure 1c,d, solid lines). Every individual SNL rat except one at the 5 week timepoint had lower withdrawal threshold and lower latency than every sham-operated rat, showing the clear group separation (Figure 1c,d, dotted lines). 


\subsection{Identification of Differently Expressed Proteins}

2.2.1. Differently Expressed Proteins Identified at 2 Weeks Post SNL

The mPFC tissues from the behaviorally tested SNL and sham rats were collected 2 weeks after the surgery and processed for 2D-ELFO. The silver-stained gels were evaluated by PDQuest software (Bio-Rad) to detect a total of 114 protein spots. Among these, 12 protein spots were recognized as significantly altered $(p<0.05)$ with at least a 1.5 -fold difference (Figure 2a,b). LC-MS /MS analysis of the 12 protein spots identified 11 proteins shown in Table 1: heat-shock cognate $71 \mathrm{kDa}$ protein (spot 1), guanine nucleotide-binding protein $\mathrm{G}(\mathrm{o})$ subunit alpha (spot 2), 14-3-3 protein epsilon (spot 3), Ras-related protein Rab-3A (spot 4), lactoylglutathione lyase (spot 5), phosphatidylethanolamine-binding protein 1 (spot 6), triosephosphate isomerase (spot 7 and spot 8), isocitrate dehydrogenase (NAD) subunit alpha, mitochondrial precursor (spot 9), malate dehydrogenase, cytoplasmic isoform MDH1 (spot 10), ubiquitin carboxyl-terminal hydrolase isozyme L1 (spot 11), and Parkinson disease protein 7 homolog isoform 2 (spot 12). A complete list of exclusive unique peptides identified by LC-MS/MS analysis is presented in Table S1. The subcellular localization and functional significance of proteins altered in post-nuclear supernatant (PNS) samples of SNL rats were determined according to the current annotations in the UniProt database (https: / / www.uniprot.org, accessed on 6 January 2022) and the NCBI (https: / / www.ncbi.nlm.nih.gov, accessed on 6 January 2022) database (Table 2, Figure 3a,b).

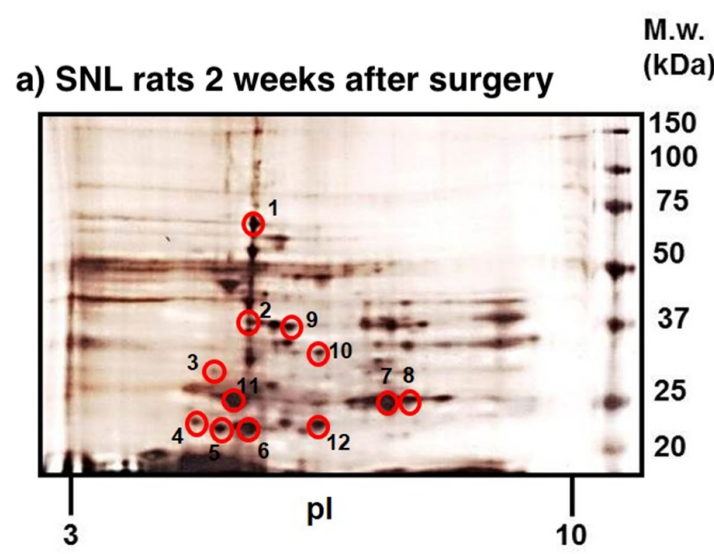

M.w.

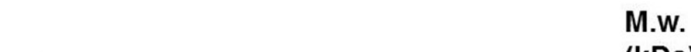

b) Sham rats 2 weeks after surgery (kDa)

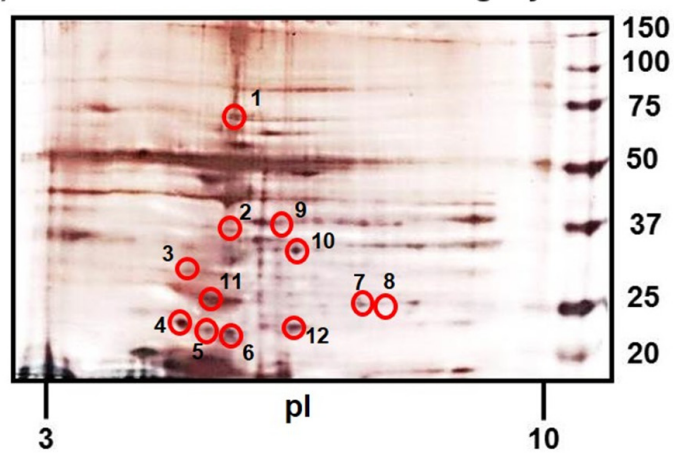

c) SNL rats 8 weeks after surgery

M.w.

(kDa) d) Sham rats 8 weeks after surgery

M.w.
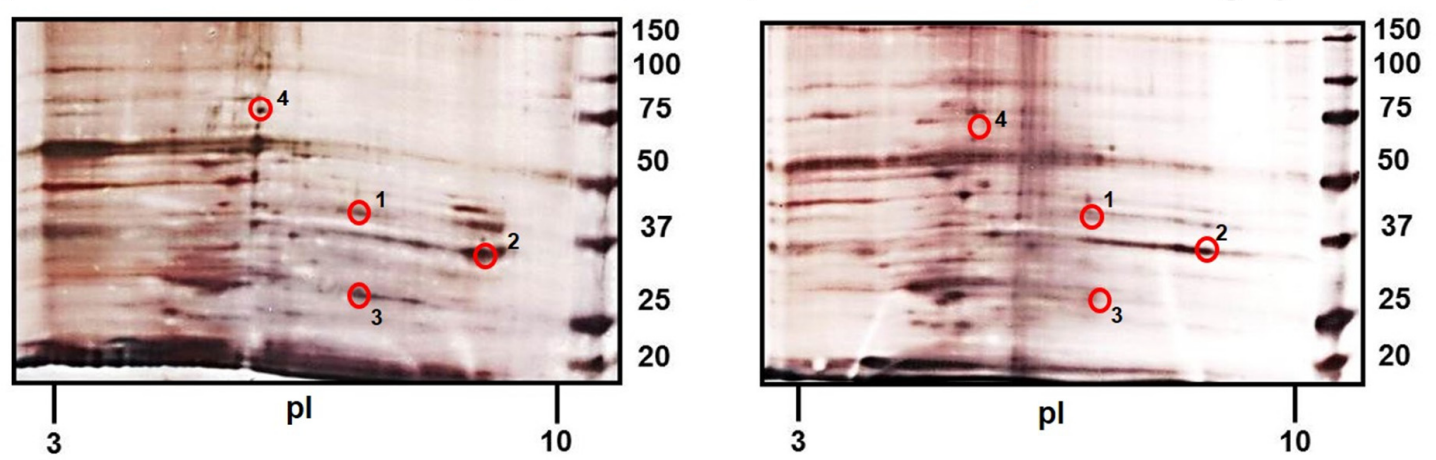

Figure 2. Representative 2D gel maps stained by silver. PNS fractions were isolated from $\mathrm{mPFC}$ of rats 2 weeks $(\mathbf{a}, \mathbf{b})$ and 8 weeks $(\mathbf{c}, \mathbf{d})$ after $(\mathbf{a}, \mathbf{c})$ SNL or $(\mathbf{b}, \mathbf{d})$ sham surgery. PNS fractions $(250 \mu \mathrm{g}$ of protein) were resolved by $2 \mathrm{D}-\mathrm{ELFO}$ and stained by ProteoSilver ${ }^{\mathrm{TM}}$ Silver Stain Kit. The differences between SNL and sham-operated rat protein maps were evaluated by PDQuest ${ }^{\mathrm{TM}}$ software (Bio-Rad, version 8.0.1). Significantly altered protein spots $(p<0.05)$ are marked with red circles (short-term effect: 1-12; long-term effect: 1-4). The spots cut out of the gels were analyzed by LC-MS/MS (two samples per spot). 
Table 1. LC-MS/MS analysis of altered protein spots in PNS fractions isolated from mPFC of SNL versus sham-operated rats 2 weeks after the surgery. The complete list of exclusive unique peptides is presented in Table S1.

\begin{tabular}{|c|c|c|c|c|c|c|c|c|}
\hline Spot & $\begin{array}{l}\text { Accession } \\
\text { Number }\end{array}$ & Protein & $\begin{array}{c}\text { Exclusive Unique } \\
\text { Peptides }\end{array}$ & $\begin{array}{l}\mathrm{SC}^{\mathrm{a}} \\
(\%)\end{array}$ & $\begin{array}{c}\mathrm{MW} \\
(\mathrm{kDa})\end{array}$ & $\mathbf{p I}^{\mathrm{b}}$ & $\begin{array}{l}\text { Change } \\
\text { (Fold) }\end{array}$ & $p$-Value \\
\hline 1 & NP_077327.1 & $\begin{array}{l}\text { Heat-shock cognate } \\
71 \mathrm{kDa} \text { protein }\end{array}$ & 23 & 69 & 71 & 5.47 & $\uparrow 2.7$ & 0.0398 \\
\hline 2 & NP_059023.1 & $\begin{array}{l}\text { Guanine nucleotide-binding } \\
\text { protein } G(0) \text { subunit alpha }\end{array}$ & 16 & 58 & 40 & 5.48 & $\uparrow 2.4$ & 0.0054 \\
\hline 3 & P62260.1 & 14-3-3 protein epsilon & 18 & 84 & 29 & 4.86 & $\uparrow 3.6$ & 0.0204 \\
\hline 4 & NP_037150.2 & Ras-related protein Rab-3A & 6 & 49 & 25 & 4.73 & $\uparrow 1.5$ & 0.0277 \\
\hline 5 & NP_997477.1 & Lactoylglutathione lyase & 10 & 56 & 21 & 5.13 & $\uparrow 1.9$ & 0.0191 \\
\hline 6 & NP_058932.1 & $\begin{array}{l}\text { Phosphatidylethanolamine- } \\
\text { binding protein } 1\end{array}$ & 8 & 62 & 21 & 5.47 & $\uparrow 1.8$ & 0.0340 \\
\hline 7 & NP_075211.2 & Triosephosphate isomerase & 14 & 71 & 27 & 7.37 & $\uparrow 2.3$ & 0.0297 \\
\hline 8 & NP_075211.2 & Triosephosphate isomerase & 13 & 64 & 27 & 7.59 & $\uparrow 3.1$ & 0.0044 \\
\hline 9 & NP_446090.1 & $\begin{array}{l}\text { Isocitrate dehydrogenase } \\
\text { (NAD) subunit alpha, } \\
\text { mitochondrial precursor }\end{array}$ & 15 & 46 & 40 & 6.13 & $\uparrow 1.6$ & 0.0116 \\
\hline 10 & NP_150238.1 & $\begin{array}{c}\text { Malate dehydrogenase, } \\
\text { cytoplasmic isoform MDH1 }\end{array}$ & 10 & 50 & 37 & 6.41 & $\uparrow 2.5$ & 0.0326 \\
\hline 11 & NP_058933.2 & $\begin{array}{l}\text { Ubiquitin carboxyl-terminal } \\
\text { hydrolase isozyme L1 }\end{array}$ & 15 & 87 & 25 & 5.24 & $\uparrow 2.8$ & 0.0110 \\
\hline 12 & $\mathrm{NP}_{-} 476484.1$ & $\begin{array}{c}\text { Parkinson disease protein } 7 \\
\text { homolog isoform } 2\end{array}$ & 9 & 72 & 20 & 6.73 & $\uparrow 3.2$ & 0.0352 \\
\hline
\end{tabular}

a Sequence coverage; ${ }^{b}$ isoelectric point; ${ }^{c}$ in SNL rats compared to sham rats.

Table 2. Subcellular localization and function of altered proteins identified in MPFC isolated from SNL versus sham-operated rats 2 weeks after the surgery.

\begin{tabular}{|c|c|c|c|}
\hline $\begin{array}{l}\text { Accession } \\
\text { Number }\end{array}$ & Protein & Subcellular Localization & Molecular Functions and Biological Processes \\
\hline NP_077327.1 & Heat-shock cognate 71 kDa protein & $\begin{array}{l}\text { nucleus, cell } \\
\text { membrane, cytoplasm }\end{array}$ & chaperone, stress response, aging, transcription \\
\hline NP_059023.1 & $\begin{array}{l}\text { Guanine nucleotide-binding protein } \\
\text { G(o) subunit alpha }\end{array}$ & cell membrane & $\begin{array}{l}\text { transducer, AC-modulating G-protein-coupled } \\
\text { receptor, signaling pathway, aging }\end{array}$ \\
\hline P62260.1 & 14-3-3 protein epsilon & nucleus, cytoplasm & $\begin{array}{l}\text { regulatory factor, signal transduction, brain } \\
\text { development, MAPK cascade }\end{array}$ \\
\hline NP_037150.2 & Ras-related protein Rab-3A & cell membrane & exocytosis, axonogenesis, protein transport \\
\hline NP_997477.1 & Lactoylglutathione lyase & $\begin{array}{l}\text { cytoplasm, nucleus, } \\
\text { cell membrane }\end{array}$ & $\begin{array}{l}\text { pyruvate metabolism, negative regulation } \\
\text { of apoptosis }\end{array}$ \\
\hline NP_058932.1 & $\begin{array}{l}\text { Phosphatidylethanolamine-binding } \\
\text { protein } 1\end{array}$ & cytoplasm, cell membrane & $\begin{array}{c}\text { protease inhibitor, aging, MAPK cascade, response } \\
\text { to wounding, response to oxidative stress }\end{array}$ \\
\hline NP_075211.2 & Triosephosphate isomerase & cytoplasm & glycolysis, gluconeogenesis \\
\hline NP_446090.1 & $\begin{array}{l}\text { Isocitrate dehydrogenase (NAD) } \\
\text { subunit alpha, mitochondrial } \\
\text { precursor }\end{array}$ & mitochondrion & Krebs cycle \\
\hline NP_150238.1 & $\begin{array}{c}\text { Malate dehydrogenase, cytoplasmic } \\
\text { isoform MDH1 }\end{array}$ & cytoplasm & Krebs cycle \\
\hline NP_058933.2 & $\begin{array}{l}\text { Ubiquitin carboxyl-terminal } \\
\text { hydrolase isozyme L1 }\end{array}$ & $\begin{array}{l}\text { cytoplasm, endoplasmic } \\
\text { reticulum, cell membrane }\end{array}$ & $\begin{array}{l}\text { ubiquitin conjugation pathway, possible role in } \\
\text { protecting cells under stress condition }\end{array}$ \\
\hline NP_476484.1 & $\begin{array}{l}\text { Parkinson disease protein } 7 \\
\text { homolog isoform } 2\end{array}$ & $\begin{array}{l}\text { cell membrane, cytoplasm, } \\
\text { nucleus, mitochondrion }\end{array}$ & $\begin{array}{l}\text { chaperone, negative regulation of apoptosis, aging, } \\
\text { response to oxidative stress, } \\
\text { inflammatory response }\end{array}$ \\
\hline
\end{tabular}




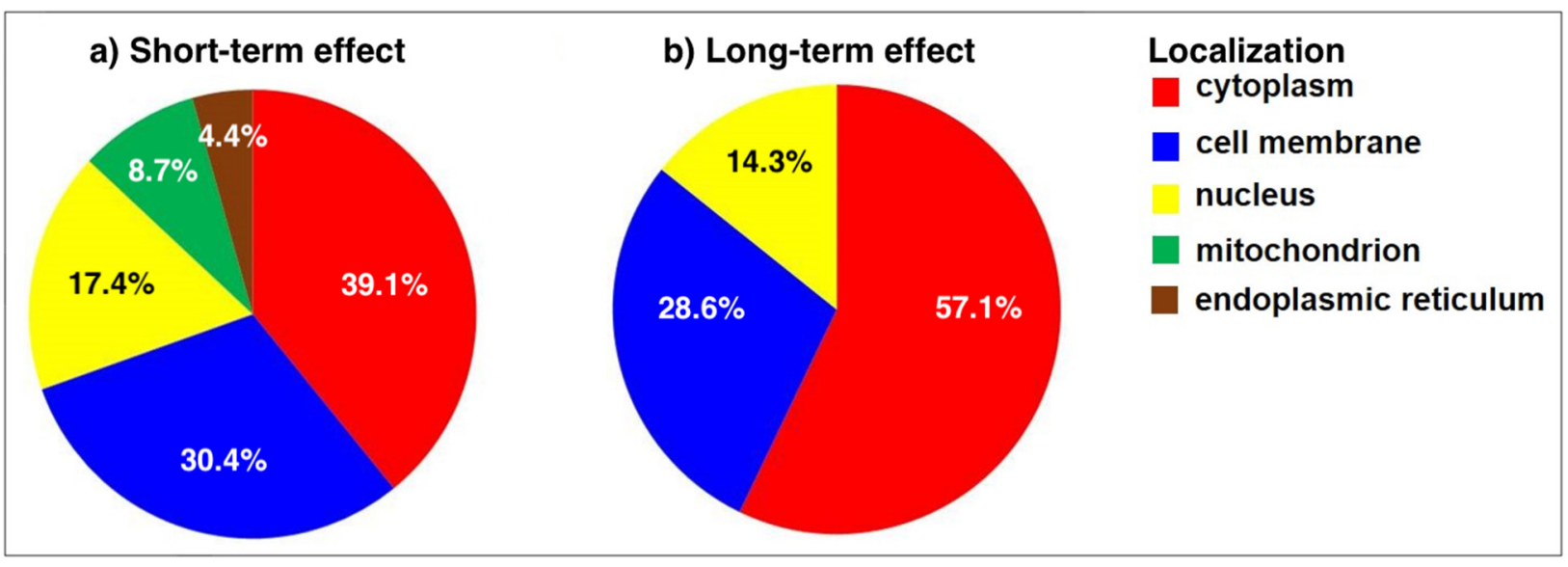

c) Short-term effect

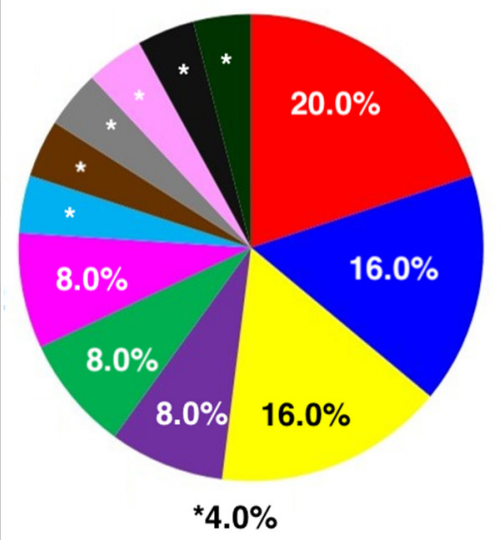

d) Long-term effect

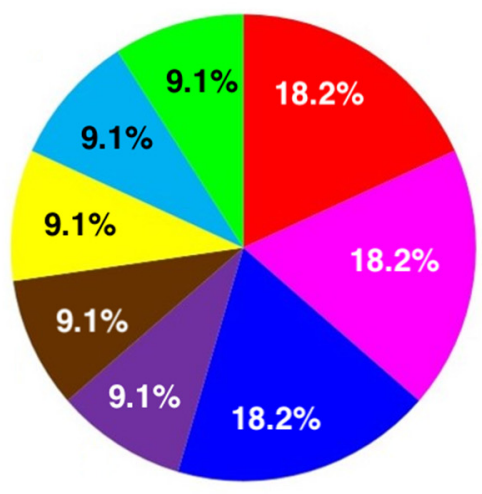

Function
$\square$ metabolism
$\square$ stress response
aging
$\square$ chaperone
signal transduction
apoptosis
$\square$ brain development
$\square$ exocytosis
$\square$ transcription
protein ubiquitination
$\square$ protease inhibitor
$\square$ inflammatory response
translation

Figure 3. Subcellular localization $(\mathbf{a}, \mathbf{b})$ and functional significance $(\mathbf{c}, \mathbf{d})$ of the proteins upregulated in the $\mathrm{mPFC}$ of SNL rats compared to sham-operated rats at 2 weeks $(\mathbf{a}, \mathbf{c})$ and 8 weeks $(\mathbf{b}, \mathbf{d})$ post surgery.

\subsubsection{Differently Expressed Proteins Identified at 8 Weeks Post SNL}

PDQuest analysis of silver-stained gels resolving mPFC samples from SNL and shamoperated rats sacrificed 8 weeks after the surgery identified a total of 106 protein spots. Only four protein spots were recognized as significantly altered $(p<0.05)$ with at least a 1.5-fold difference between two groups (Figure 2c,d) and analyzed by LC-MS/MS (Table 3): peptidyl-prolyl cis-trans isomerase D (spot 1), glyceraldehyde-3-phosphate dehydrogenase (spot 2), triosephosphate isomerase (spot 3), and dihydropyrimidinase-related protein 2 isoform X1 (spot 4). A complete list of exclusive unique peptides identified by LC-MS/MS analysis is presented in Table S2. The subcellular localization and functional significance of altered PNS samples of SNL rats were determined according to the current annotations in the UniProt database and the NCBI database (Table 4, Figure 3c,d). 
Table 3. LC-MS/MS analysis of altered protein spots in PNS fractions isolated from mPFC of SNL versus sham-operated rats 8 weeks after the surgery. The complete list of exclusive unique peptides is presented in Table S2.

\begin{tabular}{|c|c|c|c|c|c|c|c|c|}
\hline Spot & $\begin{array}{l}\text { Accession } \\
\text { Number }\end{array}$ & Protein & $\begin{array}{c}\text { Exclusive Unique } \\
\text { Peptides }\end{array}$ & $\begin{array}{l}\mathrm{SC}^{\mathrm{a}} \\
(\%)\end{array}$ & $\begin{array}{c}\text { MW } \\
(\mathbf{k D a})\end{array}$ & $\mathbf{p I}^{\mathbf{b}}$ & $\begin{array}{l}\text { Change }^{c} \\
\text { (Fold) }\end{array}$ & $p$-Value \\
\hline 1 & NP_001004279.1 & $\begin{array}{c}\text { Peptidyl-prolyl } \\
\text { cis-trans isomerase D }\end{array}$ & 17 & 49 & 41 & 7.27 & $\uparrow 2.1$ & 0.0267 \\
\hline 2 & NP_058704.1 & $\begin{array}{l}\text { Glyceraldehyde-3- } \\
\text { phosphate } \\
\text { dehydrogenase }\end{array}$ & 16 & 70 & 36 & 8.87 & $\uparrow 2.1$ & 0.0386 \\
\hline 3 & NP_075211.2 & $\begin{array}{l}\text { Triosephosphate } \\
\text { isomerase }\end{array}$ & 14 & 68 & 27 & 7.20 & $\uparrow 2.0$ & 0.0370 \\
\hline 4 & XP_006252159.1 & $\begin{array}{l}\text { Dihydropyrimidinase- } \\
\text { related protein } 2 \\
\text { isoform } \mathrm{X} 1\end{array}$ & 17 & 52 & 73 & 5.87 & $\uparrow 2.2$ & 0.0216 \\
\hline
\end{tabular}

${ }^{a}$ Sequence coverage; ${ }^{b}$ isoelectric point; ${ }^{c}$ in SNL rats compared to sham rats.

Table 4. Subcellular localization and function of altered proteins in mPFC isolated from SNL versus sham-operated rats 8 weeks after the surgery.

\begin{tabular}{cccc}
\hline Accession Number & Protein & Subcellular Localization & $\begin{array}{c}\text { Molecular Functions and } \\
\text { Biological Processes }\end{array}$ \\
\hline NP_001004279.1 & $\begin{array}{c}\text { Peptidyl-prolyl cis-trans } \\
\text { isomerase D }\end{array}$ & nucleus, cytoplasm & $\begin{array}{c}\text { chaperone, negative regulation of } \\
\text { apoptosis, protein transport, response } \\
\text { to oxidative stress }\end{array}$ \\
\hline NP_058704.1 & $\begin{array}{c}\text { Glyceraldehyde-3-phosphate } \\
\text { dehydrogenase }\end{array}$ & cytoplasm, nucleus & $\begin{array}{c}\text { glycolysis, response to oxidative stress, } \\
\text { apoptosis, regulation of translation }\end{array}$ \\
\hline NP_075211.2 & Triosephosphate isomerase & cytoplasm & glycolysis, gluconeogenesis \\
\hline XP_006252159.1 & $\begin{array}{c}\text { Dihydropyrimidinase-related } \\
\text { protein 2 isoform X1 }\end{array}$ & cytoplasm, cell membrane & $\begin{array}{c}\text { developmental protein, remodeling of } \\
\text { the cytoskeleton after injury, } \\
\text { differentiation, neurogenesis }\end{array}$ \\
\hline
\end{tabular}

\subsection{Functional Significance of Altered Proteins}

2.3.1. Functional Significance of Proteins Altered at 2 Weeks Post SNL

As shown in Table 2, 14-3-3 protein epsilon was upregulated the most (3.6-fold) 2 weeks after SNL. This phosphoserine and phosphothreonine adapter protein interacts with various targets, including kinases, phosphatases, and transmembrane receptors, and regulates various signaling pathways of receptors, including the mu-opioid receptor [31,32]. Similar to our results, a recent proteomics study [33] reported that 14-3-3 protein epsilon was overexpressed in spinal cord samples collected 10 days after SNL surgery. Although the functional relevance of these changes is unclear, 14-3-3 protein epsilon is likely to promote pain compensatory mechanisms at the early stage of chronic neuropathic pain by regulating endogenous opioid signaling pathways. Alternatively, 14-3-3 protein epsilon may play a role in central sensitization at both spinal and cortical levels to promote the sensory, affective, and cognitive consequences of neuropathic pain.

We also detected a significantly increased level of guanine nucleotide-binding protein $\mathrm{G}(\mathrm{o})$ alpha subunit $\left(\mathrm{G} \alpha_{0}, 2.4\right.$-fold, Table 1$)$. The $\mathrm{G} \alpha_{\mathrm{o}}$ protein is constitutively expressed at high levels in mammalian brain and mediates the signal transfer from G-protein-coupled receptors (GPCRs), including opioid receptors through intracellular signal transduction pathways [34]. Importantly, $\mathrm{G} \alpha_{0}$ is $5-10$-fold more abundant than other $\mathrm{G} \alpha$ proteins in the brain where it constitutes $5-10 \%$ of total membrane proteins [35]. Thus, the 2.4fold upregulation of $G \alpha_{0}$ indicates a substantial increase in $G \alpha_{0}$ signaling in rats with neuropathic pain. The increased level of $G \alpha_{0}$ was also reported in spinal cord dorsal horn 
after L5 spinal nerve ligation [36]. It is likely that upregulation of $\mathrm{G} \alpha_{\mathrm{o}}$ at early timepoints after injury stimulates the signaling of the mu-opioid receptors, possibly through the endogenous opioid analgesic mechanisms. However, upregulation of $G \alpha_{o}$ in spinal and cortical regions may also promote pain sensitization through other GPCRs.

The magnitude of upregulation of Ras-related protein Rab-3A (1.5-fold, Table 2) is comparable to upregulation (1.5- and 2.1-fold) observed in the brainstem tissues of SNL rats [37] and in the right central nucleus of the amygdala following the spinal nerve transection [38], respectively. In general, GTPases of the Rab family regulate membrane trafficking, including formation of vesicles, vesicle trafficking, and membrane fusion. Recently, Rab-3A was demonstrated to be critical for exocytosis of dense core vesicles and release of neuromodulators suggesting a role in neuronal transmission [39].

Heat-shock proteins (Hsps) participate in stabilization of a proper protein conformation in various tissues and protect cells from moderate stress. In our mPFC samples, we detected upregulation of heat-shock cognate $71 \mathrm{kDa}$ protein (Hsc71, 2.7-fold) at 2 weeks post SNL. An increase in Hsc71 level was also observed in spinal cord samples from L5 SNL [36], L5-L6 SNL [33], and chronic constriction injury animals [40]. The signaling mediated by the Hsp may represent a basic mechanism of defense against proteotoxic impairment of cell homeostasis [41]. Numerous proteins involved in cellular metabolism and homeostasis have been reported in nerve injury models [40,42]. Our proteomic analysis also revealed the increases in glycolytic enzyme triosephosphate isomerase in two spots (2.3and 3.1-fold for spot 7 and spot 8, respectively) and enzymes of the Krebs cycle: isocitrate dehydrogenase (NAD) subunit alpha (1.6-fold) and malate dehydrogenase (2.5-fold). The upregulation of metabolic enzymes after the nerve injury may be important for building up cellular defense mechanisms or for activation of metabolic pathways that are normally inactive under steady-state conditions [43]. In addition to the enzymes, the upregulation of phosphatidylethanolamine-binding protein 1 (PEBP-1) was detected. This protease inhibitor participates in the oxidative stress response.

Apoptosis was found to be functionally related to the induction of neuronal sensitization and loss of central inhibitory systems, and both processes were suggested to be linked to the development of neuropathic pain [44]. Our LC-MS/MS analysis identified the increase in lactoylglutathione lyase (1.9-fold) and Parkinson disease protein 7 homolog isoform 2 (3.2-fold), which are involved in negative regulation of apoptosis $[45,46]$. Ubiquitin carboxyl-terminal hydrolase isozyme L1, which plays a role in protecting cells under stress conditions, was also found to be upregulated (2.8-fold). A study suggested that degradation of selective protein networks by the ubiquitin proteasome system in the spinal cord may lead to the onset of neuropathic and inflammatory pain [33].

\subsubsection{Functional Significance of Proteins Altered at 8 Weeks Post SNL}

LC-MS/MS analysis identified that fewer proteins (four proteins) were upregulated at 8 weeks compared to 2 weeks after SNL (Table 3). Peptidyl-prolyl cis-trans isomerase D upregulated by 2.1-fold is known to be involved in protein folding, negative regulation of apoptosis, and response to oxidative stress [47]. Glyceraldehyde-3-phosphate dehydrogenase upregulated by 2.1-fold is a glycolytic enzyme, and its post-translational modifications may be functionally linked to oxidative stress and apoptosis [48]. Upregulation of another glycolytic enzyme, triosephosphate isomerase, was detected in the mPFC at both 2 weeks (spots 7 (2.3-fold) and 8 (3.1-fold) in Figure 2a,b) and 8 weeks after SNL (spot 3 (2.0-fold) in Figure $2 \mathrm{c}, \mathrm{d}$ ). The persistence of triosephosphate isomerase upregulation from 2 to 8 weeks after development of neuropathic pain (compare Tables 1-4) indicates that this enzyme is involved in both short- and long-term neuropathic pain states. Dihydropyrimidinaserelated protein 2 isoform X1, a developmental protein, upregulated by 2.2 -fold has been shown to play a role in remodeling of cytoskeleton after nerve injury [49]. 


\section{Discussion}

In this study, we focused on pain-induced changes in protein composition in the $\mathrm{mPFC}$ that has been demonstrated to play a role in a wide range of functions, including the processing of sensory and affective aspects of pain, cognitive evaluation, and modulation of pain in both human and animal studies. In rodents, immunostaining studies of activitydependent early genes provided strong evidence of neuronal activation in the mPFC in response to acute and persistent pain [50]. Electrophysiological studies showing longterm potentiation in $\mathrm{mPFC}$ slices of injured animals further supported the conclusion that mPFC hyperexcitability contributes to chronic pain [51]. Although several molecules for ion channels, receptors, kinases, and signal transduction have been found to promote pain-related synaptic plasticity in the $\mathrm{MPFC}$, a systematic and time-dependent proteomic analysis in the $\mathrm{mPFC}$ has not yet been conducted. Therefore, to investigate the time-related progression of molecular mechanisms in the mPFC during chronic pain, we conducted proteomic analyses of mPFC samples at early ( 2 weeks) and late ( 8 weeks) timepoints after induction of chronic neuropathic pain.

We performed 2D-ELFO, the most commonly used method in proteomics, to analyze protein changes in the mPFC of rats at early and late timepoints following SNL surgery. Despite known problems associated with poor detection of proteins that are expressed in very small amounts (such as GPCR) or those exhibiting a low molecular mass, a low isoelectric point, or a high degree of hydrophobicity [52-55], gel-based proteomics represents a useful tool for identification of pain-related changes in protein expression [44]. We applied the high-sensitivity and low-background silver stain ProteoSilver ${ }^{\mathrm{TM}}$ method that is compatible with mass spectrometry analysis. To the best of our knowledge, this is the first proteomic comparison of the MPFC of SNL-treated and sham-operated rats at early and late timepoints following peripheral nerve injury-induced pain.

The Hargreaves and von Frey tests clearly showed that SNL rats established persistent neuropathic pain: thermal hyperalgesia and tactile allodynia (Figure 1). Our previous studies showed that approximately 10\% [56] of male Sprague-Dawley rats are resilient to developing SNL-induced peripheral hypersensitivity due to efficient descending pain inhibition from the brain. We also showed that, in resilient SNL rats, these mechanisms ultimately engage the rostral ventromedial medulla (RVM) [56], while other studies additionally identified a role for the ACC and $\mathrm{mPFC}$ projections to periaqueductal gray (PAG) and RVM in pain modulation [23]. This descending pain-protective mechanism has been characterized in a majority of healthy volunteers $[57,58]$, partially explaining why most people do not develop chronic neuropathic pain after nerve injury. However, the descending pain inhibition is inefficient in some individuals that are prospectively more likely to develop chronic pain after a scheduled surgical procedure [59]. To avoid confounding factors from possible neural adaptations in the mPFC that may exist in resilient animals, and to analyze the same number of rats in each group $(n=9)$, we chose the highest pain responders from the SNL groups (18 out of 25 rats). Likewise, we excluded four out of 22 rats that showed partial hypersensitivity following sham surgery.

Proteomic analysis of silver-stained spots in 2D gels identified two different sets of proteins that were altered during the short- and long-term periods, respectively. At 2 weeks after surgery, 12 protein spots were found significantly altered in SNL rats compared to sham-operated rats. Notable among these proteins was the upregulation of signal transduction molecules: $14-3-3$ protein epsilon, $\mathrm{G} \alpha_{\mathrm{o}}$ subunit of an inhibitory $\mathrm{G}$ protein, and a small GTPase, Ras-related protein Rab-3A. These findings suggest increased neural signaling in the $\mathrm{mPFC}$, which may be consistent with findings that glutamatergic activation of ACC promotes aversive behavior [26], and that lesions of the ACC relieve ongoing neuropathic pain [28]. The increased neural signaling in the mPFC may also reflect the engagement of endogenous pain compensatory mechanisms at the early timepoints during the injury. Other proteins identified by the analysis were those involved in cellular metabolism, stress, apoptosis, and the ubiquitin proteasome pathway. These cellular functions may serve protective roles against increased cellular stress during the early (subacute) neuropathic pain. 
At 8 weeks, however, only four protein spots were found to differ significantly between SNL and sham-operated rats. These proteins included chaperones and proteins involved in apoptosis and remodeling of the cytoskeleton. Interestingly, one of these proteins, dihydropyrimidinase-related protein 2 (also known as collapsin response mediator protein-2, or CRMP-2) is known for its function in several pathophysiological and disease states including chronic pain [60]. CRMP-2 is highly expressed in the nervous system and was shown to interact with the presynaptic N-type voltage-gated calcium channel (Cav2.2) in sensory neurons facilitating nociceptive transmission at the spinal level and promoting neuropathic pain [61]. A study found that, in rats, repeated cocaine self-administration resulted in dynamic alterations in the PFC expression of CRMP2 and CaV2.2, suggesting that neuroadaptations in the CRMP2/CaV2.2 signaling in the PFC facilitate drug-seeking behavior [62]. It is plausible that similar CRMP2 sensitization mechanisms may take place in the $\mathrm{mPFC}$ during a long-term period to maintain chronic pain.

A comparison of proteins altered at the early and late timepoints indicated that the mPFC undergoes significant and time-dependent remodeling during the progression of ongoing neuropathic pain. This interpretation is consistent with the dynamic reorganization of the mPFC function during pain chronification that has been observed in longitudinal neuroimaging studies in both rats and humans $[5,30,63,64]$. Only one protein, triosephosphate isomerase, was observed to be persistently upregulated at both timepoints. It may be speculated that at least some protein adaptations in the early time period are related to pain compensatory mechanisms involving endogenous opioid signaling. These early adaptive mechanisms appear to be lost during pain chronification. At the same time, maladaptive changes develop that facilitate the maintenance of chronic pain and the emergence of affective and cognitive comorbidities.

In conclusion, our study demonstrated that protein expressions in rat $\mathrm{mPFC}$ were time-dependently altered in response to persistent and chronic neuropathic pain. The alterations involved proteins for signal transduction, cellular metabolism, and remodeling of the cytoskeleton, suggesting that these adaptations may underlie synaptic plasticity and functional changes to modulate pain behavior. Our findings that the changes in mPFC protein composition occurred over time after nerve injury are consistent with neural reorganization observed during pain chronification in patients [6] and may reflect paincompensatory or pain-promoting mechanisms.

\section{Materials and Methods}

\subsection{Chemicals}

The 10\% Mini-Protean ${ }^{\circledR}$ Protein Gels 7 cm IPG/prep well, IPG ReadyStrip ${ }^{\mathrm{TM}} \mathrm{pH} 3-10$, Bio-Lyte $^{\circledR}$ 3-10 Buffer, Mineral Oil, and Precision Plus Protein ${ }^{\mathrm{TM}}$ were purchased from BioRad (Hercules, CA, USA). The Complete ${ }^{\mathrm{TM}}$ Protease Inhibitor Cocktail and Pierce ${ }^{\mathrm{TM}}$ BCA Protein Assay Kit were purchased from Roche (Indianapolis, IN, USA) and Thermo Fisher Scientific (Waltham, MA, USA), respectively. The Trypsin/Lysine-C mix and ProteaseMax Surfactant trypsin enhancer were purchased from Promega Corporation (Madison, WI, USA). All other chemicals, including ProteoSilver ${ }^{\mathrm{TM}}$ Silver Stain Kit, were purchased from Sigma-Aldrich (St. Louis, MO, USA).

\subsection{Animals}

Male Sprague-Dawley rats, 250-300 g, were obtained from Harlan Laboratories (Indianapolis, IN, USA). Animals were group-housed on a 12 h/12 h light/dark cycle. Food and water were available ad libitum. All described procedures received approval from the Institutional Animal Care and Use Committee (IACUC) of the University of Arizona (15-589). Animals were monitored throughout the study following the International Association for the Study of Pain ethical guidelines. Investigators for all behavioral experiments were blinded to the treatment groups. 


\subsection{Surgeries}

SNL surgery was performed as described previously [65]. Rats were maintained under $2 \% v / v$ isoflurane anesthesia delivered in a 3:2 ratio of nitrous oxide and oxygen. A paraspinal incision was made, and the left tail muscle was excised. Part of the L5 transverse process was removed to expose the L5 and L6 spinal nerves, which were then isolated and ligated with a nonabsorbable 6-0 braided silk thread proximal to the formation of the sciatic nerve. The surrounding skin and muscles were closed with absorbable 3-0 sutures. Sham surgery was also performed in an identical manner skipping the ligation step. All rats were monitored for normal behaviors (grooming and mobility), general health, and weight gain after the surgery.

\subsection{Behavioral Tests}

\subsubsection{Von Frey Tests}

Paw-withdrawal thresholds were measured by von Frey tests. Rats were placed in suspended chambers with wire mesh floors for $30 \mathrm{~min}$ to habituate before the test. A series of calibrated von Frey filaments (Stoelting, Wood Dale, IL, USA) in logarithmically spaced increments ranging from 0.41 to $15 \mathrm{~g}(4-150 \mathrm{~N})$ were applied perpendicularly to the plantar surface of the ipsilateral hind paw until the filament buckled. Withdrawal threshold was determined by sequentially increasing and decreasing the stimulus strength ("up and down" method), analyzed using a Dixon nonparametric test, and expressed as the mean withdrawal threshold [66].

\subsubsection{Hargreaves Tests}

Paw-withdrawal latencies were measured by Hargreaves tests [67]. Rats were allowed to acclimate in Plexiglas enclosures with raised glass floors for $30 \mathrm{~min}$ before the test. After acclimation, a radiant heat source (115 V, UGO Basile Biological Research Apparatus Model 7371, Comerio VA, Italy) was positioned under the glass floor directly beneath the hind paw. The radiant heat source was activated with a reaction time counter (timer), and paw-withdrawal latency was determined by a motion-sensitive detector source that halted both the timer and the heat source when the hind paw was withdrawn. The withdrawal latency to the nearest $0.1 \mathrm{~s}$ was automatically recorded. Baseline latencies were established at 17 to $25 \mathrm{~s}$ to allow a sufficient window for the detection of possible hyperalgesia. A maximal cutoff of $33 \mathrm{~s}$ was used to prevent tissue damage.

\subsubsection{Test Groups}

A total of 48 rats were randomly assigned to four groups: (1) sham $/ 2$ week (11 rats); (2) SNL/2 week (13 rats); (3) sham/8 week (11 rats); 4) SNL/8 week (13 rats). Baseline tactile and thermal responses for groups 1 and 2 and groups 3 and 4 were measured on two consecutive days, and surgeries were performed 1 day after baseline testing. A total of three rats were removed before the tests because of low baseline thresholds or death during the surgery. In the 2 week groups, mechanical and thermal hypersensitivities were evaluated on day 12 or 13. For the protein analysis, two groups of mPFC tissue were collected from nine sham rats with the highest post-surgical withdrawal latencies and nine SNL rats with the lowest post-surgical withdrawal latencies, respectively. The tissues were harvested on day 18 ( 2 week groups) after the surgery. Rats in the 8 week groups were evaluated for mechanical and thermal hypersensitivity on days $12 / 13$ ( 2 weeks) and again on days 38 ( 5 weeks) and 52 ( 7 weeks) after the surgery. For the protein analysis, two groups of $\mathrm{mPFC}$ tissue were collected from nine sham rats with the highest post-surgical withdrawal latencies and nine SNL rats with the lowest post-surgical withdrawal latencies, respectively. The tissues were harvested on day 59 (8 week groups).

\subsubsection{Statistical Analysis}

All graphs were created and statistical analyses were performed in GraphPad Prism 9. Two-way repeated-measures ANOVA was performed with time after the surgery as the 
within-subject factor and the surgery as the between-subject factor. Sidak's multiplecomparisons test was performed to assess the differences between the groups. Significance was set at $p<0.05$.

\subsection{Preparation of PNS Fraction from mPFC Tissues of SNL/Sham-Operated Rats}

For the collection of $\mathrm{mPFC}$ tissue, a $3 \mathrm{~mm}$ coronal slice of the brain tissue approximately between Bregma $+3.5 \mathrm{~mm}$ and Bregma $+0.5 \mathrm{~mm}$ was cut, and a $2 \mathrm{~mm}$ midline section ( $1 \mathrm{~mm}$ on each side) above the corpus callosum was extracted. The mPFC tissues from three animals within the same group were pooled into one sample of approximately $0.1 \mathrm{~g}$ : three sham/2 week, three sham/8 week, three SNL/2 week, and three SNL/8 week samples. The tissue was diluted with STEM medium (250 mM sucrose, $20 \mathrm{mM}$ Tris- $\mathrm{HCl}, 1 \mathrm{mM}$ ethylenediamine tetraacetic acid (EDTA), $3 \mathrm{mM} \mathrm{MgCl}_{2}, \mathrm{pH} 7.6$ ) containing $1 \mathrm{mM}$ fresh phenylmethylsulfonyl fluoride and protease inhibitor cocktail, homogenized mildly in a loosely fitting Teflon-glass homogenizer for $7 \mathrm{~min}(0.1 \mathrm{~g}$ wet weight per $0.5 \mathrm{~mL})$, and centrifuged for $5 \mathrm{~min}$ at $3500 \mathrm{rpm}$. PNS samples were immediately analyzed for protein concentration using Pierce ${ }^{\mathrm{TM}}$ BCA Protein Assay Kit (Thermo Scientific, Waltham, MA, USA) and were then stored at $-80^{\circ} \mathrm{C}$. More PNS fractions were prepared in the same manner approximately 8 weeks after the surgery.

\subsection{D-ELFO}

\subsubsection{Sample Preparation for Isoelectric Focusing (IEF)}

Samples of PNS containing $250 \mu \mathrm{g}$ of protein were precipitated with ice-cold acetone overnight at $-20{ }^{\circ} \mathrm{C}$. After centrifugation at $12,000 \mathrm{rpm}$ for $20 \mathrm{~min}$ at $4{ }^{\circ} \mathrm{C}$, the supernatant was removed, and the pellet was precipitated with ice-cold $6 \%$ trichloroacetic acid for $1.5 \mathrm{~h}$ in an ice bath. After the second centrifugation at $12,000 \mathrm{rpm}$ for $10 \mathrm{~min}$ at $4{ }^{\circ} \mathrm{C}$, the supernatant was discarded, and the pellet was washed with $200 \mu \mathrm{L}$ of ice-cold $96 \%$ ethanol for $1 \mathrm{~h}$ at room temperature. The mixture was centrifuged at 12,000 rpm for $10 \mathrm{~min}$ at $4{ }^{\circ} \mathrm{C}$, and the remaining pellet was dissolved in $140 \mu \mathrm{L}$ of IEF sample buffer containing $7 \mathrm{M}$ urea, $2 \mathrm{M}$ thiourea, 4\% 3-((3-cholamidopropyl)dimethylammonio)-1-propanesulfonic acid, $1 \%$ dithiothreitol (DTT), $0.2 \%$ ampholines $\mathrm{pH} 3-10$, and $0.01 \%$ bromophenol blue for $3 \mathrm{~h}$ at room temperature. After a brief centrifugation $(12,000 \mathrm{rpm}, 1 \mathrm{~min})$, samples were transferred into a groove of the rehydration tray. Immobilized $\mathrm{pH}$ gradient (IPG) strips $\mathrm{pH}$ 3-10 were placed into the rehydration tray, and the samples were rehydrated overnight. IEF was performed using the Protean ${ }^{\circledR}$ IEF cell system (Bio-Rad, Hercules, CA, USA) under mineral oil at $15{ }^{\circ} \mathrm{C}$ in the following manner: $250 \mathrm{~V}$ for $20 \mathrm{~min}$, linear gradient; $500 \mathrm{~V}$ for $1 \mathrm{~h}$, linear gradient; $1000 \mathrm{~V}$ for $1 \mathrm{~h}$, linear gradient; $4000 \mathrm{~V}$ for $1 \mathrm{~h}$, linear gradient; $4000 \mathrm{~V}$ for $20,000 \mathrm{Vh}$, rapid gradient. The focused strips were stored at $-20^{\circ} \mathrm{C}$ or immediately used.

\subsubsection{Equilibration of IPG Strips and SDS-PAGE}

The focused strips were rinsed thoroughly with ultrapure water, equilibrated in $4 \mathrm{~mL}$ of equilibration buffer (50 mM Tris- $\mathrm{HCl}$ pH 6.8, $6 \mathrm{M}$ urea, $0.1 \mathrm{mM}$ EDTA, 2\% sodium dodecyl sulfate, 30\% glycerol, and $0.01 \%$ bromophenol blue) containing 1\% DTT for $20 \mathrm{~min}$ to reduce disulfide bridges and other oxidized groups. Subsequently, the strips were alkylated in an equilibration buffer containing 2.5\% iodoacetamide for $20 \mathrm{~min}$. Precision Plus Protein Standard markers were loaded onto a piece of filter paper and placed close to the alkaline side of the strip. The strip and paper containing protein markers were covered with $0.5 \%$ agarose. Gels were run in the Mini-Protean Tetra Cell system at $50 \mathrm{~V}$ for $5 \mathrm{~min}$ and $150 \mathrm{~V}$ for approximately $45 \mathrm{~min}$ until the bromophenol blue dye reached the end of the gel. At least nine 2D gels were performed with PNS samples prepared from each test group.

\subsection{Silver Staining}

Silver staining was performed using ProteoSilver ${ }^{\mathrm{TM}}$ Silver Stain Kit (Sigma-Aldrich, St. Louis, MO, USA) according to the manufacturer's instructions [68,69]. Briefly, a gel was fixed in 50\% ethanol/10\% acetic acid for $2 \mathrm{~h}$ and then washed with $30 \%$ ethanol for $10 \mathrm{~min}$ 
followed by a $10 \mathrm{~min}$ wash with $200 \mathrm{~mL}$ of ultrapure water. The gel was incubated for $10 \mathrm{~min}$ with $1 \%$ sensitizer solution and washed twice with $200 \mathrm{~mL}$ of ultrapure water for $10 \mathrm{~min}$. The gel was submerged in 1\% silver solution for $10 \mathrm{~min}$, washed with $200 \mathrm{~mL}$ of ultrapure water for $1 \mathrm{~min}$, and developed with $100 \mathrm{~mL}$ of the developer solution until desired intensity of spots was attained. The ProteoSilver Stop solution was added to the developer solution, and gel was incubated for $5 \mathrm{~min}$. All steps were carried out at room temperature on an orbital shaker at 60 to $70 \mathrm{rpm}$. The gel was stored in $1 \%$ acetic acid at $4{ }^{\circ} \mathrm{C}$.

\subsection{Image Analysis}

The stained 2D gels were scanned and quantified by PDQuest 2D Analysis Software (Bio-Rad, version 8.0.1). The process included spot detection, gel matching, and spot quantification. All matched and unmatched spots were then checked manually. First, 2D gels prepared from the mPFC samples of SNL or sham rats 2 weeks after the surgery were evaluated. Second, 2D gels of the mPFC samples collected 8 weeks after SNL or sham surgery were analyzed. Protein spots showing significant quantitative differences of at least 1.5 -fold ( $p<0.05$, Student's $t$-test) were manually cut out from the gels for the analyses.

\subsection{Identification of Proteins}

Protein identification was performed by the Proteomics Core of the University of Arizona (https://proteomics.arizona.edu, accessed on 20 December 2021). The silverstained gel spots were destained with $30 \mathrm{mM}$ sodium ferricyanide and $100 \mathrm{mM}$ sodium thiosulfate. Disulfide bonds were reduced with DTT, and the resulting free cysteines were alkylated with iodoacetamide before overnight digestion in $50 \mathrm{mM}$ ammonium bicarbonate (pH 7.8), containing $20 \mathrm{ng} / \mu \mathrm{L}$ trypsin/lysine $\mathrm{C}$ and ProteaseMax Surfactant trypsin enhancer, at $37^{\circ} \mathrm{C}$. LC-MS/MS analyses were carried out using a Q Exactive Plus mass spectrometer (Thermo Fisher Scientific, San Jose, CA, USA) equipped with a nanoESI source. Peptides were eluted from an Acclaim PepMap 100 trap column $(3 \mu \mathrm{m}, 75 \mu \mathrm{m}$ ID $\times 25 \mathrm{~mm}$, Thermo Scientific) onto an Acclaim PepMap RSLC analytical column $(2 \mu \mathrm{m}$, $75 \mu \mathrm{m}$ ID $\times 15 \mathrm{~cm}$, Thermo Scientific) using a 5-20\% gradient of solvent B (acetonitrile, $0.1 \%$ formic acid) over $50 \mathrm{~min}, 20-50 \%$ solvent B over $5 \mathrm{~min}, 50-95 \%$ of solvent B over $3 \mathrm{~min}, 95 \%$ hold of solvent B for $5 \mathrm{~min}$, and finally a return to $5 \%$ solvent B in $1 \mathrm{~min}$ and another $10 \mathrm{~min}$ hold of $5 \%$ solvent B. Solvent A consisted of $0.1 \%$ formic acid in water. All flow rates were $300 \mathrm{~nL} /$ min using a Dionex Ultimate 3000 RSLCnano System (Thermo Scientific). Data-dependent scanning was performed by the Xcalibur v 4.0.27.19 software [70] using a survey scan at 70,000 resolution scanning mass/charge $(\mathrm{m} / \mathrm{z})$ 353-1550 at an automatic gain control (AGC) target of $1 \times 10^{5}$ and a maximum injection time (IT) of $65 \mathrm{~ms}$, followed by higher-energy collisional dissociation (HCD) tandem mass spectrometry (MS/MS) at 27 normalized collision energy (NCE), of the 10 most intense ions at a resolution of 17,500 , an isolation width of $1.5 \mathrm{~m} / \mathrm{z}$, an AGC of $1 \times 10^{5}$, and a maximum IT of $65 \mathrm{~ms}$ [70-72]. Dynamic exclusion was set to place any selected $\mathrm{m} / \mathrm{z}$ on an exclusion list for $20 \mathrm{~s}$ after a single MS/MS. Ions of charge state $+1,7,8,>8$, and unassigned were excluded from MS/MS, as were isotopes. Tandem mass spectra were searched against the Rattus norvegicus protein database from NCBI (13 November 2018, 83,019 sequences) to which additional common contaminant proteins (e.g., trypsin, keratins; obtained at fttps:/ / ftp.thegpm.org/fasta/cRAP, accessed on 13 November 2018) were appended. All MS/MS spectra were searched using Thermo Proteome Discoverer v 2.2.0388 (Thermo Fisher Scientific) considering fully tryptic peptides with up to two missed cleavage sites. Variable modifications considered during the search included methionine oxidation (15.995 Da), and cysteine carbamidomethylation (57.021 Da). Proteins were identified at 99\% confidence with XCorr score cutoffs [72] as determined by a reversed database search. The protein and peptide identification results were also visualized with Scaffold $Q+S \mathrm{v}$ 4.8.7 (Proteome Software Inc., Portland OR), a program that relies on various search engine results (e.g., Sequest, X!Tandem, MASCOT) and which uses Bayesian statistics to reliably identify more spectra [71]. Protein identifications were accepted that passed a minimum 
of two peptides identified at a $0.1 \%$ peptide false discovery rate and $90-99.9 \%$ protein confidence by the Protein Profit algorithm within Scaffold.

Supplementary Materials: The following are available online https:/ / www.mdpi.com/article/10.3390/ ijms23020955/s1.

Author Contributions: Conceptualization, H.U., P.S., Y.S.L. and E.N.; methodology, H.U., D.R. and X.Y.; software, H.U.; validation, analysis, and writing, H.U. and E.N.; review and editing, P.S. and Y.S.L. All authors read and agreed to the published version of the manuscript.

Funding: This work was supported by the National Institutes on Drug Abuse (grant number R01DA041809), by the European Structural and Investment Funds, Operational Programme Research, Development, and Education “IPHYS Mobility" (grant number CZ.02.2.69/0.0/0.0/16_027/0008013), by the NIH/NCI (grant number CA023074) to the University of Arizona Cancer Center, UA Research Development and Innovation Office, and by the BIO5 Institute of the University of Arizona.

Institutional Review Board Statement: All described procedures received approval from the Institutional Animal Care and Use Committee (IACUC) of the University of Arizona (15-589).

Informed Consent Statement: Not applicable.

Data Availability Statement: The mass spectrometry proteomics data were deposited to the ProteomeXchange Consortium via the PRIDE partner repository under dataset identifiers.

Conflicts of Interest: The authors declare no conflict of interest.

\section{References}

1. Emery, E.C.; Luiz, A.P.; Wood, J.N. Nav1.7 and other voltage-gated sodium channels as drug targets for pain relief. Expert Opin. Ther. Targets 2016, 20, 975-983. [CrossRef] [PubMed]

2. Mapplebeck, J.C.S.; Lorenzo, L.E.; Lee, K.Y.; Gauthier, C.; Muley, M.M.; De Koninck, Y.; Prescott, S.A.; Salter, M.W. Chloride Dysregulation through Downregulation of KCC2 Mediates Neuropathic Pain in Both Sexes. Cell Rep. 2019, 28, 590-596.e4. [CrossRef]

3. Coull, J.A.; Boudreau, D.; Bachand, K.; Prescott, S.A.; Nault, F.; Sik, A.; De Koninck, P.; De Koninck, Y. Trans-synaptic shift in anion gradient in spinal lamina I neurons as a mechanism of neuropathic pain. Nature 2003, 424, 938-942. [CrossRef] [PubMed]

4. Farmer, M.A.; Baliki, M.N.; Apkarian, A.V. A dynamic network perspective of chronic pain. Neurosci. Lett. 2012, 520, 197-203. [CrossRef]

5. Baliki, M.N.; Petre, B.; Torbey, S.; Herrmann, K.M.; Huang, L.; Schnitzer, T.J.; Fields, H.L.; Apkarian, A.V. Corticostriatal functional connectivity predicts transition to chronic back pain. Nat. Neurosci. 2012, 15, 1117-1119. [CrossRef] [PubMed]

6. Apkarian, A.V.; Baliki, M.N.; Farmer, M.A. Predicting transition to chronic pain. Curr. Opin. Neurol. 2013, 26, 360-367. [CrossRef]

7. Tracey, I.; Bushnell, M.C. How neuroimaging studies have challenged us to rethink: Is chronic pain a disease? J. Pain Off. J. Am. Pain Soc. 2009, 10, 1113-1120. [CrossRef]

8. Harris, R.E.; Napadow, V.; Huggins, J.P.; Pauer, L.; Kim, J.; Hampson, J.; Sundgren, P.C.; Foerster, B.; Petrou, M.; Schmidt-Wilcke, T.; et al. Pregabalin rectifies aberrant brain chemistry, connectivity, and functional response in chronic pain patients. Anesthesiology 2013, 119, 1453-1464. [CrossRef]

9. Iannetti, G.D.; Zambreanu, L.; Wise, R.G.; Buchanan, T.J.; Huggins, J.P.; Smart, T.S.; Vennart, W.; Tracey, I. Pharmacological modulation of pain-related brain activity during normal and central sensitization states in humans. Proc. Natl. Acad. Sci. USA 2005, 102, 18195-18200. [CrossRef]

10. Oertel, B.G.; Preibisch, C.; Wallenhorst, T.; Hummel, T.; Geisslinger, G.; Lanfermann, H.; Lotsch, J. Differential opioid action on sensory and affective cerebral pain processing. Clin. Pharmacol. Ther. 2008, 83, 577-588. [CrossRef]

11. Rauck, R.; Coffey, R.J.; Schultz, D.M.; Wallace, M.S.; Webster, L.R.; McCarville, S.E.; Grigsby, E.J.; Page, L.M. Intrathecal gabapentin to treat chronic intractable noncancer pain. Anesthesiology 2013, 119, 675-686. [CrossRef] [PubMed]

12. Hama, A.; Natsume, T.; Ogawa, S.Y.; Awaga, Y.; Hayashi, I.; Matsuda, A.; Takamatsu, H. Pain-Related Behavior and Brain Activation in a Cynomolgus Macaque Model of Postoperative Pain. CNS Neurol. Disord. Drug Targets 2018, 17, 348-360. [CrossRef]

13. Bannister, K.; Qu, C.; Navratilova, E.; Oyarzo, J.; Xie, J.Y.; King, T.; Dickenson, A.H.; Porreca, F. Multiple sites and actions of gabapentin-induced relief of ongoing experimental neuropathic pain. Pain 2017, 158, 2386-2395. [CrossRef]

14. Navratilova, E.; Xie, J.Y.; Meske, D.; Qu, C.; Morimura, K.; Okun, A.; Arakawa, N.; Ossipov, M.; Fields, H.L.; Porreca, F. Endogenous opioid activity in the anterior cingulate cortex is required for relief of pain. J. Neurosci. 2015, 35, 7264-7271. [CrossRef]

15. Johansen, J.P.; Fields, H.L.; Manning, B.H. The affective component of pain in rodents: Direct evidence for a contribution of the anterior cingulate cortex. Proc. Natl. Acad. Sci. USA 2001, 98, 8077-8082. [CrossRef] 
16. Bushnell, M.C.; Ceko, M.; Low, L.A. Cognitive and emotional control of pain and its disruption in chronic pain. Nat. Rev. Neurosci. 2013, 14, 502-511. [CrossRef]

17. Villemure, C.; Bushnell, M.C. Mood influences supraspinal pain processing separately from attention. J. Neurosci. Off. J. Soc. Neurosci. 2009, 29, 705-715. [CrossRef]

18. Wager, T.D.; Rilling, J.K.; Smith, E.E.; Sokolik, A.; Casey, K.L.; Davidson, R.J.; Kosslyn, S.M.; Rose, R.M.; Cohen, J.D. Placeboinduced changes in FMRI in the anticipation and experience of pain. Science 2004, 303, 1162-1167. [CrossRef] [PubMed]

19. Hsieh, J.C.; Belfrage, M.; Stone-Elander, S.; Hansson, P.; Ingvar, M. Central representation of chronic ongoing neuropathic pain studied by positron emission tomography. Pain 1995, 63, 225-236. [CrossRef]

20. Willoch, F.; Gamringer, U.; Medele, R.; Steude, U.; Tolle, T.R. Analgesia by electrostimulation of the trigeminal ganglion in patients with trigeminopathic pain: A PET activation study. Pain 2003, 103, 119-130. [CrossRef]

21. Becerra, L.; Navratilova, E.; Porreca, F.; Borsook, D. Analogous Responses in the Nucleus Accumbens and Cingulate Cortex to Pain Onset (Aversion) and Offset (Relief) in Rats and Humans. J. Neurophysiol. 2013, 110, 1221-1226. [CrossRef] [PubMed]

22. Zhang, Z.; Gadotti, V.M.; Chen, L.; Souza, I.A.; Stemkowski, P.L.; Zamponi, G.W. Role of Prelimbic GABAergic Circuits in Sensory and Emotional Aspects of Neuropathic Pain. Cell Rep. 2015, 12, 752-759. [CrossRef] [PubMed]

23. Huang, J.; Gadotti, V.M.; Chen, L.; Souza, I.A.; Huang, S.; Wang, D.; Ramakrishnan, C.; Deisseroth, K.; Zhang, Z.; Zamponi, G.W. A neuronal circuit for activating descending modulation of neuropathic pain. Nat. Neurosci. 2019, 22, 1659-1668. [CrossRef] [PubMed]

24. Price, T.J.; Ray, P.R. Recent advances toward understanding the mysteries of the acute to chronic pain transition. Curr. Opin. Physiol. 2019, 11, 42-50. [CrossRef]

25. Zubieta, J.K.; Stohler, C.S. Neurobiological mechanisms of placebo responses. Ann. N. Y. Acad. Sci. 2009, 1156, 198-210. [CrossRef]

26. Johansen, J.P.; Fields, H.L. Glutamatergic activation of anterior cingulate cortex produces an aversive teaching signal. Nat. Neurosci. 2004, 7, 398-403. [CrossRef]

27. LaGraize, S.C.; Labuda, C.J.; Rutledge, M.A.; Jackson, R.L.; Fuchs, P.N. Differential effect of anterior cingulate cortex lesion on mechanical hypersensitivity and escape/avoidance behavior in an animal model of neuropathic pain. Exp. Neurol. 2004, 188, 139-148. [CrossRef]

28. Qu, C.; King, T.; Okun, A.; Lai, J.; Fields, H.L.; Porreca, F. Lesion of the rostral anterior cingulate cortex eliminates the aversiveness of spontaneous neuropathic pain following partial or complete axotomy. Pain 2011, 152, 1641-1648. [CrossRef] [PubMed]

29. Hashmi, J.A.; Baliki, M.N.; Huang, L.; Baria, A.T.; Torbey, S.; Hermann, K.M.; Schnitzer, T.J.; Apkarian, A.V. Shape shifting pain: Chronification of back pain shifts brain representation from nociceptive to emotional circuits. Brain 2013,136 Pt 9, $2751-2768$. [CrossRef]

30. Seminowicz, D.A.; Laferriere, A.L.; Millecamps, M.; Yu, J.S.C.; Coderre, T.J.; Bushnell, M.C. MRI structural brain changes associated with sensory and emotional function in a rat model of long-term neuropathic pain. NeuroImage 2009, 47, 1007-1014. [CrossRef]

31. Ajit, S.K.; Ramineni, S.; Edris, W.; Hunt, R.A.; Hum, W.T.; Hepler, J.R.; Young, K.H. RGSZ1 interacts with protein kinase C interacting protein PKCI-1 and modulates mu opioid receptor signaling. Cell. Signal. 2007, 19, 723-730. [CrossRef] [PubMed]

32. Sanchez-Blazquez, P.; Rodriguez-Munoz, M.; Montero, C.; de la Torre-Madrid, E.; Garzon, J. Calcium/calmodulin-dependent protein kinase II supports morphine antinociceptive tolerance by phosphorylation of glycosylated phosducin-like protein. Neuropharmacology 2008, 54, 319-330. [CrossRef] [PubMed]

33. Sui, P.; Watanabe, H.; Ossipov, M.H.; Bakalkin, G.; Artemenko, K.; Bergquist, J. Proteomics of neuropathic pain: Proteins and signaling pathways affected in a rat model. J. Proteome Res. 2014, 13, 3957-3965. [CrossRef]

34. Milligan, G.; Kostenis, E. Heterotrimeric G-proteins: A short history. Br. J. Pharmacol. 2006, 147 (Suppl 1), S46-S55. [CrossRef]

35. Jiang, M.; Bajpayee, N.S. Molecular mechanisms of go signaling. Neurosignals 2009, 17, 23-41. [CrossRef]

36. Singh, O.V.; Yaster, M.; Xu, J.T.; Guan, Y.; Guan, X.; Dharmarajan, A.M.; Raja, S.N.; Zeitlin, P.L.; Tao, Y.X. Proteome of synaptosomeassociated proteins in spinal cord dorsal horn after peripheral nerve injury. Proteomics 2009, 9, 1241-1253. [CrossRef]

37. Alzate, O.; Hussain, S.R.; Goettl, V.M.; Tewari, A.K.; Madiai, F.; Stephens, R.L., Jr.; Hackshaw, K.V. Proteomic identification of brainstem cytosolic proteins in a neuropathic pain model. Brain Res. Mol. Brain Res. 2004, 128, 193-200. [CrossRef]

38. Karu, K.; Swanwick, R.S.; Novejarque-Gadea, A.; Antunes-Martins, A.; Thomas, B.; Yoshimi, E.; Foster, W.; Fang, M.; McMahon, S.B.; Bennett, D.L.H.; et al. Quantitative Proteomic Analysis of the Central Amygdala in Neuropathic Pain Model Rats. J. Proteome Res. 2020, 19, 1592-1619. [CrossRef]

39. Persoon, C.M.; Hoogstraaten, R.I.; Nassal, J.P.; van Weering, J.R.T.; Kaeser, P.S.; Toonen, R.F.; Verhage, M. The RAB3-RIM Pathway Is Essential for the Release of Neuromodulators. Neuron 2019, 104, 1065-1080.e12. [CrossRef] [PubMed]

40. Zou, W.; Zhan, X.; Li, M.; Song, Z.; Liu, C.; Peng, F.; Guo, Q. Identification of differentially expressed proteins in the spinal cord of neuropathic pain models with PKCgamma silence by proteomic analysis. Brain Res. 2012, 1440, 34-46. [CrossRef] [PubMed]

41. Calabrese, V.; Scapagnini, G.; Ravagna, A.; Giuffrida Stella, A.M.; Butterfield, D.A. Molecular chaperones and their roles in neural cell differentiation. Dev. Neurosci. 2002, 24, 1-13. [CrossRef]

42. Zou, W.; Xu, W.; Song, Z.; Zhong, T.; Weng, Y.; Huang, C.; Li, M.; Zhang, C.; Zhan, X.; Guo, Q. Proteomic Identification of an Upregulated Isoform of Annexin A3 in the Spinal Cords of Rats in a Neuropathic Pain Model. Front. Neurosci. 2017, 11, 484. [CrossRef] [PubMed] 
43. Komori, N.; Takemori, N.; Kim, H.K.; Singh, A.; Hwang, S.H.; Foreman, R.D.; Chung, K.; Chung, J.M.; Matsumoto, H. Proteomics study of neuropathic and nonneuropathic dorsal root ganglia: Altered protein regulation following segmental spinal nerve ligation injury. Physiol. Genom. 2007, 29, 215-230. [CrossRef] [PubMed]

44. Niederberger, E.; Geisslinger, G. Proteomics in neuropathic pain research. Anesthesiology 2008, 108, 314-323. [CrossRef]

45. Taniguchi, H.; Horinaka, M.; Yoshida, T.; Yano, K.; Goda, A.E.; Yasuda, S.; Wakada, M.; Sakai, T. Targeting the glyoxalase pathway enhances TRAIL efficacy in cancer cells by downregulating the expression of antiapoptotic molecules. Mol. Cancer Ther. 2012, 11, 2294-2300. [CrossRef] [PubMed]

46. Dolgacheva, L.P.; Berezhnov, A.V.; Fedotova, E.I.; Zinchenko, V.P.; Abramov, A.Y. Role of DJ-1 in the mechanism of pathogenesis of Parkinson's disease. J. Bioenerg. Biomembr. 2019, 51, 175-188. [CrossRef]

47. Dunyak, B.M.; Gestwicki, J.E. Peptidyl-Proline Isomerases (PPIases): Targets for Natural Products and Natural Product-Inspired Compounds. J. Med. Chem. 2016, 59, 9622-9644. [CrossRef]

48. Chuang, D.M.; Hough, C.; Senatorov, V.V. Glyceraldehyde-3-phosphate dehydrogenase, apoptosis, and neurodegenerative diseases. Annu. Rev. Pharmacol. Toxicol. 2005, 45, 269-290. [CrossRef]

49. Indraswari, F.; Wong, P.T.; Yap, E.; Ng, Y.K.; Dheen, S.T. Upregulation of Dpysl2 and Spna2 gene expression in the rat brain after ischemic stroke. Neurochem. Int. 2009, 55, 235-242. [CrossRef]

50. Lei, L.G.; Zhang, Y.Q.; Zhao, Z.Q. Pain-related aversion and Fos expression in the central nervous system in rats. Neuroreport 2004, 15, 67-71. [CrossRef]

51. Bliss, T.V.; Collingridge, G.L.; Kaang, B.K.; Zhuo, M. Synaptic plasticity in the anterior cingulate cortex in acute and chronic pain. Nat. Rev. Neurosci. 2016, 17, 485-496. [CrossRef] [PubMed]

52. Ujcikova, H.; Vosahlikova, M.; Roubalova, L.; Svoboda, P. Proteomic analysis of protein composition of rat forebrain cortex exposed to morphine for 10days; comparison with animals exposed to morphine and subsequently nurtured for 20days in the absence of this drug. J. Proteom. 2016, 145, 11-23. [CrossRef] [PubMed]

53. Baggerman, G.; Vierstraete, E.; De Loof, A.; Schoofs, L. Gel-based versus gel-free proteomics: A review. Comb. Chem. High Throughput Screen. 2005, 8, 669-677. [CrossRef]

54. Gauci, V.J.; Wright, E.P.; Coorssen, J.R. Quantitative proteomics: Assessing the spectrum of in-gel protein detection methods. J. Chem. Biol. 2011, 4, 3-29. [CrossRef]

55. Gygi, S.P.; Rist, B.; Gerber, S.A.; Turecek, F.; Gelb, M.H.; Aebersold, R. Quantitative analysis of complex protein mixtures using isotope-coded affinity tags. Nat. Biotechnol. 1999, 17, 994-999. [CrossRef] [PubMed]

56. De Felice, M.; Sanoja, R.; Wang, R.; Vera-Portocarrero, L.; Oyarzo, J.; King, T.; Ossipov, M.H.; Vanderah, T.W.; Lai, J.; Dussor, G.O.; et al. Engagement of descending inhibition from the rostral ventromedial medulla protects against chronic neuropathic pain. Pain 2011, 152, 2701-2709. [CrossRef]

57. Yarnitsky, D. Role of endogenous pain modulation in chronic pain mechanisms and treatment. Pain 2015, 156 (Suppl 1), S24-S31. [CrossRef]

58. Yarnitsky, D. Conditioned pain modulation (the diffuse noxious inhibitory control-like effect): Its relevance for acute and chronic pain states. Curr. Opin. Anaesthesiol. 2010, 23, 611-615. [CrossRef] [PubMed]

59. Yarnitsky, D.; Crispel, Y.; Eisenberg, E.; Granovsky, Y.; Ben-Nun, A.; Sprecher, E.; Best, L.A.; Granot, M. Prediction of chronic post-operative pain: Pre-operative DNIC testing identifies patients at risk. Pain 2008, 138, 22-28. [CrossRef]

60. Moutal, A.; White, K.A.; Chefdeville, A.; Laufmann, R.N.; Vitiello, P.F.; Feinstein, D.; Weimer, J.M.; Khanna, R. Dysregulation of CRMP2 Post-Translational Modifications Drive Its Pathological Functions. Mol. Neurobiol. 2019, 56, 6736-6755. [CrossRef] [PubMed]

61. Moutal, A.; Yang, X.; Li, W.; Gilbraith, K.B.; Luo, S.; Cai, S.; Francois-Moutal, L.; Chew, L.A.; Yeon, S.K.; Bellampalli, S.S.; et al. CRISPR/Cas9 editing of Nf1 gene identifies CRMP2 as a therapeutic target in neurofibromatosis type 1-related pain that is reversed by (S)-Lacosamide. Pain 2017, 158, 2301-2319. [CrossRef]

62. Buchta, W.C.; Moutal, A.; Hines, B.; Garcia-Keller, C.; Smith, A.C.W.; Kalivas, P.; Khanna, R.; Riegel, A.C. Dynamic CRMP2 Regulation of CaV2.2 in the Prefrontal Cortex Contributes to the Reinstatement of Cocaine Seeking. Mol. Neurobiol. 2020, 57, 346-357. [CrossRef]

63. Metz, A.E.; Yau, H.J.; Centeno, M.V.; Apkarian, A.V.; Martina, M. Morphological and functional reorganization of rat medial prefrontal cortex in neuropathic pain. Proc. Natl. Acad. Sci. USA 2009, 106, 2423-2428. [CrossRef]

64. Hubbard, C.S.; Khan, S.A.; Xu, S.; Cha, M.; Masri, R.; Seminowicz, D.A. Behavioral, metabolic and functional brain changes in a rat model of chronic neuropathic pain: A longitudinal MRI study. Neuroimage 2015, 107, 333-344. [CrossRef] [PubMed]

65. Kim, S.H.; Chung, J.M. An experimental model for peripheral neuropathy produced by segmental spinal nerve ligation in the rat. Pain 1992, 50, 355-363. [CrossRef]

66. Dixon, W.J. Efficient analysis of experimental observations. Annu. Rev. Pharmacol. Toxicol. 1980, 20, 441-462. [CrossRef] [PubMed]

67. Hargreaves, K.; Dubner, R.; Brown, F.; Flores, C.; Joris, J. A new and sensitive method for measuring thermal nociception in cutaneous hyperalgesia. Pain 1988, 32, 77-88. [CrossRef]

68. Rabilloud, T.; Vuillard, L.; Gilly, C.; Lawrence, J.J. Silver-staining of proteins in polyacrylamide gels: A general overview. Cell Mol. Biol. 1994, 40, 57-75. [PubMed] 
69. Gharahdaghi, F.; Weinberg, C.R.; Meagher, D.A.; Imai, B.S.; Mische, S.M. Mass spectrometric identification of proteins from silver-stained polyacrylamide gel: A method for the removal of silver ions to enhance sensitivity. Electrophoresis 1999, 20, 601-605. [CrossRef]

70. Andon, N.L.; Hollingworth, S.; Koller, A.; Greenland, A.J.; Yates, J.R., 3rd; Haynes, P.A. Proteomic characterization of wheat amyloplasts using identification of proteins by tandem mass spectrometry. Proteomics 2002, 2, 1156-1168. [CrossRef]

71. Keller, A.; Nesvizhskii, A.I.; Kolker, E.; Aebersold, R. Empirical statistical model to estimate the accuracy of peptide identifications made by MS/MS and database search. Anal. Chem. 2002, 74, 5383-5392. [CrossRef] [PubMed]

72. Qian, W.J.; Liu, T.; Monroe, M.E.; Strittmatter, E.F.; Jacobs, J.M.; Kangas, L.J.; Petritis, K.; Camp, D.G., 2nd; Smith, R.D. Probabilitybased evaluation of peptide and protein identifications from tandem mass spectrometry and SEQUEST analysis: The human proteome. J. Proteome Res. 2005, 4, 53-62. [CrossRef] [PubMed] 